\title{
Essential oil of Lippia alba (Mill.) N.E.Br. influences the germination, vigor and emergence of lettuce seeds
}

\section{El aceite esencial de Lippia alba (Mill.) N.E.Br. influye en la germinación, vigor y emergencia de semillas de lechuga}
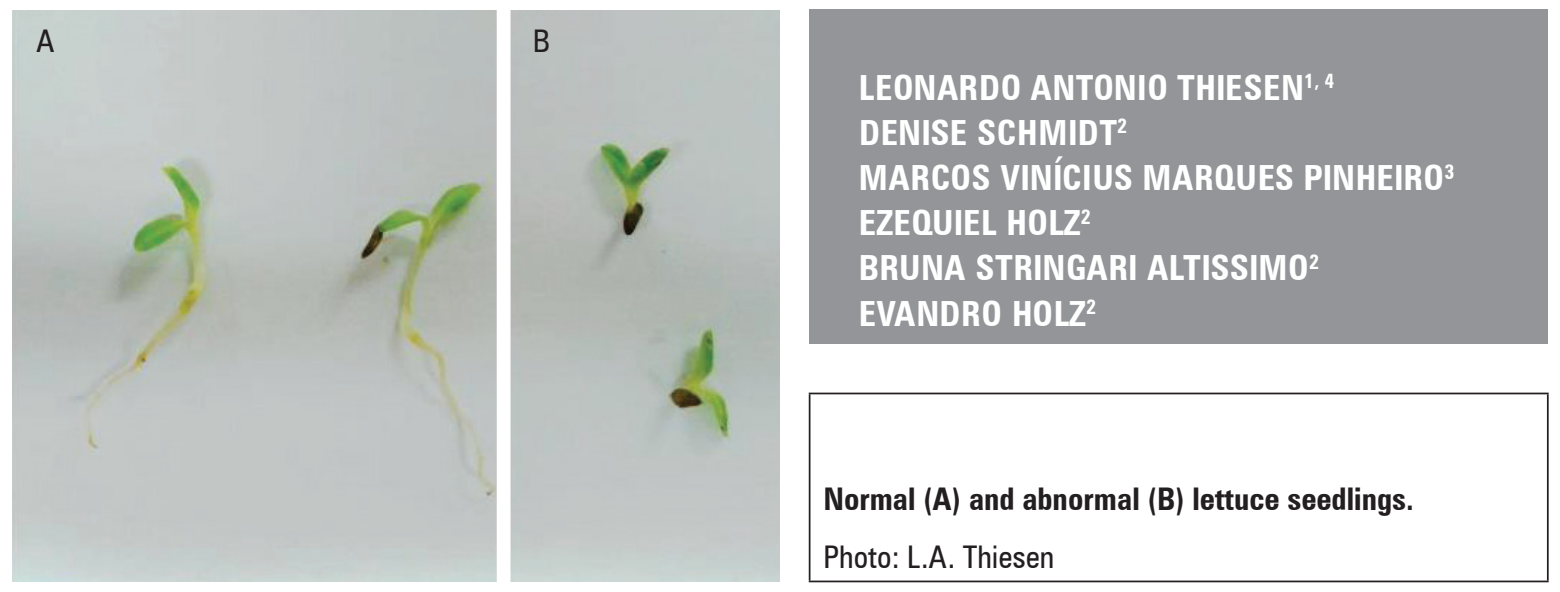

\section{ABSTRACT}

Secondary metabolites are produced by certain plant species and may influence the development of some species through the action of allelopathic effects. Thus, the objective of this study was to evaluate the allelopathic effect of Lippia alba essential oil on the germination, emergence and vigor of seedlings of different batches of lettuce seeds. This experiment was conducted in a completely randomized design with a $3 \times 5$ factorial scheme consisting of three batches of seeds of the cultivar Grand Rapids ${ }^{\circledR}$ and five doses of $L$. alba essential oil $(0,0.25,0.50,0.75$ and $1.00 \%)$ diluted in distilled water and homogenized in Tween ${ }^{\circledR} 80$. Seed germination and vigor, in the laboratory (experiment I), and emergence, in a protected environment (experiment II), were evaluated. The results demonstrated that there was an inhibitory effect with a significant reduction of germination, vigor and seed emergence when $L$. alba essential oil was added starting at concentrations of $0.25 \%$. The essential oil showed allelopathic potential over different lettuce seed lots, affecting germination, vigor and seed emergence.

Additional keywords: Lactuca sativa L.; false lemon balm; allelopathy; secondary metabolites.

Federal University of Santa Maria, Department of Biology, Santa Maria (Brazil). ORCID Thiesen, L.A.: 0000-00023439-842X

2 Federal University of Santa Maria, Frederico Westphalen Campus, Departament of Agronomic and Environmental Sciences, Frederico Westphalen (Brazil). ORCID Schmidt, D.: 0000-0002-9963-4956; ORCID Holz, E.: 0000-00023154-863X; Altissimo, B.S.: 0000-0002-5618-5775; Holz, E.: 0000-0002-8018-6743

3 State University of Maranhão, Graduate Program in Agriculture and Environment, Sao Luis (Brazil). ORCID Pinheiro, M.V.M.: 0000-0002-5028-7818

4 Corresponding author. thiesen07@hotmail.com 


\section{RESUMEN}

Los metabolitos secundarios son producidos por ciertas especies de plantas, y pueden influir en el desarrollo de algunas especies, debido a la acción de los efectos alelopáticos. Por lo tanto, el objetivo del trabajo fue evaluar el efecto alelopático del aceite esencial de Lippia alba en la germinación, emergencia y vigor de las plántulas de diferentes lotes de semillas de lechuga. El experimento se realizó en un diseño completamente al azar, en un esquema factorial $3 \times 5$, que consta de tres lotes de semillas del cultivar Grand Rapids ${ }^{\circledR}$ y cinco dosis de aceite esencial de L. alba (0; $0,25 ; 0,50 ; 0,75$ y $1,00 \%)$ diluido en agua destilada y homogeneizado en Tween ${ }^{\circledR} 80$. Se evaluó la germinación y el vigor de la semilla en el laboratorio (experimento I) y la emergencia en un ambiente protegido (experimento II). Los resultados obtenidos mostraron que hubo un efecto inhibitorio con una reducción significativa de la germinación, el vigor y la emergencia de la semilla cuando se añadió aceite esencial de L. alba a partir de concentraciones de $0.25 \%$. El aceite esencial mostró potencial alelopático sobre diferentes lotes de semillas de lechuga, afectando la germinación, el vigor y la emergencia de las semillas.

Palabras clave adicionales: Lactuca sativa L.; falso bálsamo de limón; alelopatía; metabolitos secundarios.

Received for publication: 24-05-2018 Accepted for publication: 29-11-2019

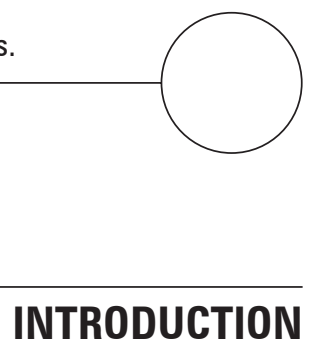

Allelopathy is a chemical phenomenon in plants that produces certain secondary metabolites that, when released into the environment, positively or negatively influence the germination and development of other species that inhabit the same environment, which has contributed significantly to the adaptive evolution of vegetables (Ferreira et al., 2007; Gliessman, 2009; Taiz et al., 2017). This allelopathic effect occurs as a result of the presence of these secondary metabolites in different plant structures, with different active ingredient composition for each species (Mirmostafaee et al., 2020).

Usually, secondary metabolites are produced as a defense mechanism against biotic or abiotic stress conditions or are synthesized to provide plant-plant, plant-microorganism and plant- animal interactions (Arceo-Medina et al., 2016). Because of these interactions, the volatile compounds of secondary metabolites can diffuse in the air and affect neighboring organisms (Mirmostafaee et al., 2020). Also, they can attract insects, promoting pollination and seed dispersion. Among these secondary metabolites, essential oil stands out, which can perform different biological functions depending on the different constituents produced. For these reasons, the effect of essential oils has been studied in the search for new alternatives that are more sustainable and less toxic to the environment and humans, geared towards management and diversification of agricultural crops (Li et al., 2011; Gusman et al., 2012).

Among the species that produce essential oils, mainly aromatic plants, Lippia alba (Verbenaceae) is notable, popularly known as false lemon balm, lemon balm, melissa false, lemon tree, Brazilian lemongrass, lemongrass, board tea or wild rosemary (Oliveira et al., 2019; Santos et al., 2019). It is a plant rich in essential oil with notable chemotype limonene, citral, cavone and linalool levels, with bactericidal, fungicidal, nematicidal, mild sedative and anticancer action (Tavares et al., 2005; Fabri et al., 2011; Oliveira et al., 2018) and analgesic, anti-inflammatory, sedative and antispasmodic activities (Tavares et al., 2011; MamunOr-Rashid et al., 2013). L. alba essential oil can also cause phytotoxicity, as seen in watermelon seedlings (Citrullus lanatus Thunb.) and rice (Oryza sativa L.) with concentrations of 4\% (Brum et al., 2014).

The resistance or tolerance to certain secondary metabolism compounds is characteristic of each plant species. Among the species most sensitive to the effects of secondary metabolites, cucumber, tomato and lettuce stand out (Garbim et al., 2015). Lettuce is considered a model plant for assessing allelopathic potential because of its fast and uniform germination and high sensitivity to allelopathic substances (Mirmostafaee et al., 2020). Therefore, the objective 
of the study was to evaluate the influence of $L$. alba essential oil on the germination, vigor and emergence of lettuce seeds from different commercial lots.

\section{MATERIALS AND METHODS}

This study was conducted at the Federal University of Santa Maria, Frederico Westphalen Campus, geographically located at $27^{\circ} 23^{\prime} \mathrm{S}, 53^{\circ} 25^{\prime} \mathrm{W}$ and $493 \mathrm{~m}$ altitude. The climate of the region is of the Cfa type - humid subtropical, rainy, temperate, and average annual precipitation of $1,800 \mathrm{~mm}$ that is well distributed throughout the year according to the Köppen classification (Alvares et al., 2013).

For the allelopathy test of the essential oil of Lippia alba, lettuce cultivar Grand Rapids ${ }^{\circledR}$ was used. The seeds came from three commercial lots, with lot 1 showing germination of 92 and $100 \%$ purity and lots 2 and 3 showing germination and purity of 97 and $99.9 \%$, respectively.

The essential oil used in the tests was extracted from fresh L. alba leaves taken from adult plants without flowering collected from the medicinal garden located at the Federal University of Santa Maria, Frederico Westphalen Campus. The extraction of the essential oil was carried out with the hydrodistillation process, with a modified Clevenger apparatus, for a period of $2 \mathrm{~h}$. For this, the plant material was chopped and added in a volumetric flask together with distilled water. The balloon was placed in thermal blankets for heating. After detecting the beginning of the boil, $2 \mathrm{~h}$ were timed, corresponding to the period of hydrodistillation. After this period, the oil was removed, added to amber glass bottles and stored in the dark in a refrigerator at $5^{\circ} \mathrm{C}$.

\section{Experiment I: Allelopathy of the essential oil of $L$. alba in the germination and vigor lettuce seeds}

Experiment I was carried out from January 28 to February 11, 2016 at the Seed Laboratory with a completely randomized experiment design in a $3 \times 5$ factorial arrangement with three commercial seeds lots and five doses of $L$. alba essential oil [0\%; $0.25 \%$; $0.50 \% ; 0.75 \%$ and $1 \%,(\mathrm{v} / \mathrm{v})$ ], totaling 15 treatments, with four repetitions per treatment. The experiment unit was composed of 100 seeds per repetition.
The solutions in the different concentrations of $L$. alba essential oil were prepared by diluting the essential oil in distilled water, homogenized in Tween ${ }^{\circledR}$ 80 , at a concentration of $1 \%(v / v)$. Sowing of the lettuce was carried out in a transparent acrylic gerbox box, $11 \times 11 \times 4 \mathrm{~cm}$, with a substrate of two sheets of germitest paper. The paper was moistened with a solution of different concentrations of essential oil in an amount of 2.5 times the mass of the dry germitest paper. In each box, 33 to 34 seeds were added with homogeneous spacing, totaling 100 seeds per repetition and 400 seeds per treatment. The gerboxes remained in a B.O.D. with a temperature of $25^{\circ} \mathrm{C}$ and photoperiod of $12 \mathrm{~h}$.

After $7 \mathrm{~d}$ of sowing, the following variables were evaluated: percentage of germinated seeds, first count of normal seedlings, percentage of normal seedlings, percentage of abnormal seedlings, radicle length, shoot length and dry mass of seedlings. In addition, the number of seeds germinated daily was counted to determine the germination speed index (GSI). After obtaining the daily data, the GSI was calculated using the formula established by Maguire (1962), which is based on the sum of emerged seedlings divided by the days after sowing. For the other evaluated variables, those seeds that showed radicle protrusion were considered germinated, expressed as a percentage. The evaluation of abnormal, normal seedlings and germinated seeds was carried out according to the criteria established by MAPA (2009), expressed as a percentage.

For evaluations of radicle length, shoot length and dry mass of seedlings, 20 random seedlings (considered normal) per repetition were selected. To be considered normal seedlings, these must have a root system in perfect condition, normal seedlings germinated on the fourth day after sowing were quantified, expressed as a straight hypocotyl, two green cotyledons and a well-developed coleoptile. Therefore, seedlings that showed different characteristics were considered abnormal following the recommendations of MAPA (2009).

\section{Experiment II: Influence of seed treatment with essential oil of $L$. alba during emergence and growth of lettuce in a protected environment}

Experiment II was conducted from September 18, 2015 to October 9, 2015 in a protected environment, 
built with galvanized steel and a pampean arch, $20 \mathrm{~m}$ long, $10 \mathrm{~m}$ wide and $3.5 \mathrm{~m}$ high.

The experiment was conducted in a completely randomized design in a $3 \times 5$ factorial arrangement with three commercial seed lots and five doses of the essential oil of L. alba (Mill.) [0\%; 0.25\%, 0.50\%, 0.75\% and $1 \%,(v / v)]$, totaling 15 treatments, with four repetitions per treatment. The experiment unit consisted of 50 seeds per repetition.

The sowing was carried out in expanded polystyrene trays with 200 cells, filled with commercial substrate and with $60 \%$ field capacity. Each cell received a seed, allocated at a depth of three times its size. To evaluate the effect of $L$. alba essential oil, the seeds were kept submerged in the different concentrations of essential oil solution for one minute, then they were dried on paper towels to remove the excess essential oil and sown (methodology planned by the group). Irrigation was carried out manually with the aid of a watering can, observing the water need of the crop.

After $21 \mathrm{~d}$ of sowing, the following variables were evaluated: percentage of seedling emergence, Emergence Speed Index (ESI), root length, shoot length and dry mass of seedling. For evaluation of emergence, the emerged seedlings were counted, transformed into a percentage. The ESI was determined by counting seedlings that emerged daily, and evaluations were carried out at the same time. After obtaining the daily data, the variable ESI was calculated using the formula established by Maguire (1962), based on the sum of emerged seedlings divided by the days after sowing. The root length, shoot length and dry mass of seedling were determined with a random selection of 20 seedlings per treatment, with subsequent washing of the root system.

The results of both experiments were subjected to analysis of variance to evaluate the effect of the different commercial seed lots and the concentrations of the L. alba essential oil. When significant, the averages of the qualitative data of the variables were compared with the Tukey test at 5\% probability, and, for the quantitative data, a regression analysis was performed, with the significance of the regression and coefficients being verified with the $\mathrm{F}$ test $(P \leq 0.05)$ and $\mathrm{t}$ test $(P \leq 0.05)$, respectively. The regression adjustment was performed using the adjusted determination coefficient $\left(R^{2}\right)$. The data of the variables were analyzed using the statistical program SISVAR (Ferreira, 2011).

\section{RESULTS AND DISCUSSION}

\section{Experiment I: Allelopathy of the $L$. alba essential oil in the germination and vigor of lettuce seeds}

In the analysis of variance for the variables percentage of normal seedlings, percentage of abnormal seedlings, GSI and first count of normal seedlings, there was a significant interaction between the factors according to the F test; that is, between the doses of essential oil of $L$. alba and seed lots. For the variables percentage of germinated seeds and radicle length, there was a difference only for the individual factors for the doses of essential oil of $L$. alba and seed lots $(P \leq 0.05)$. For the variables shoot length and dry mass of seedlings, there was a significant difference only for the dose of essential oil.

The variable percentage of germinated seeds had a cubic tendency, with a high percentage of germinated seeds in the environment without the presence of essential oil (90\%). When L. alba essential oil was added, there was a drastic reduction in the percentage of germinated seeds (Fig. 1). Thus, $0.25 \%$ of the essential oil had an inhibitory effect on the germination of the lettuce seeds.

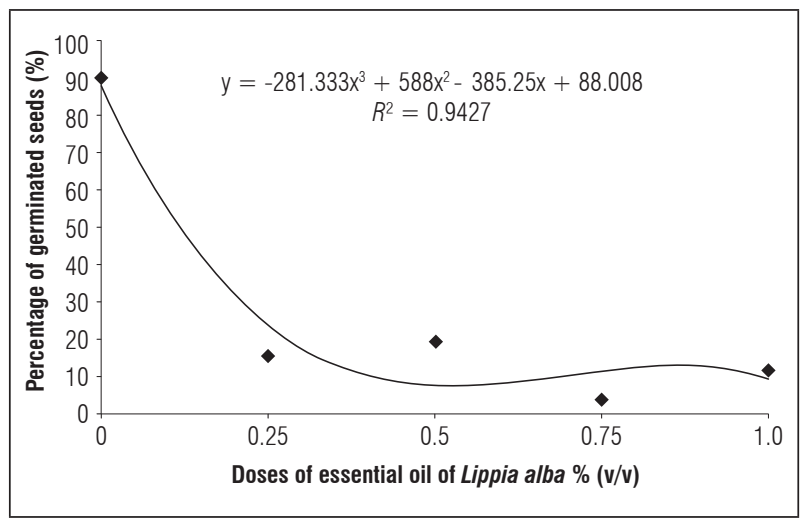

Figure 1. Percentage of germinated lettuce seeds at different doses of $L$. alba essential oil.

The essential oil produced by aromatic plants can perform several functions related to plant interactions and are also important sources of allelochemicals (Saharkhix et al., 2010). These allelochemicals are produced through the secondary metabolism of plants, forming complex compounds (Ma et al., 2012) that can affect the germination of some species. 
Therefore, the essential oil of $L$. alba tends to have allelochemicals with the ability to reduce seed germination, as was observed in the lettuce seeds in the present study. Research results with lemongrass (Cymbopogon citratus), alfavaca (Ocimum gratissimum) and basil (Ocimum basilicum) have shown that, with an increase in essential oil doses, the values related to the percentage of seeds germinated in the first count increased (Miranda et al., 2015b). Likewise, Silva et al. (2009) found that, with the increase in the concentration of the essential oil of acariçoba (Hydrocotyle bonarensis), as a result of the volatile effect, there was a restriction on germination, root length and shoot length in lettuce. The essential oil of thyme (Thymus vulgaris) also caused a negative allelopathic effect on the germination and vigor of lettuce seeds (Miranda et al., 2015a).

Results diverging from that observed in this study were found by Marco et al. (2015), in which there was no significant difference in germination and in the emergence speed index of lettuce and cabbage seeds submitted to germination in a substrate moistened with essential oil from candela (Vanillosmopsis arborea) at doses of $0.25,0.5$ and $1 \mathrm{ml} \mathrm{L}^{-1}$. However, germination and Emergence Speed Index were higher for lettuce than for cabbage. These results demonstrate that there is variability in the essential oil components of plants, some of which may have an allelopathic effect on other crops, while other plants do not have or require doses high enough to cause significant effects.

For the variable percentage of normal seedlings, it was observed that all the lots, despite presenting small differences, also adjusted to the cubic trend curve, proving that when $\mathrm{L}$ alba essential oil was added, there was a decrease in this variable (Fig. 2A). For the values of percentage of abnormal seedlings, lots 2 and 3 followed the same response; however, with a quadratic trend line, a similar performance was observed, reducing the percentage of abnormal seedlings with increasing doses of $L$. alba essential oil. For lot 1, there was a decrease in the percentage of abnormal seedlings at a dose of $0.5 \%$ (Fig. $2 \mathrm{~B}$ ). This decrease in the percentage of abnormal seedlings is directly related to the reduction in the percentage of germinated seeds as a result of the increase in essential oil doses.

For the variables first count of normal seedlings (Fig. 3A) and GSI (Fig. 3B), the tendency of the equations was similar, in which it was possible to adjust the cubic response. For both variables, there was a drastic reduction in the average already at the dose of $0.25 \%$. The application of $L$. alba essential oil significantly reduced the vigor of the seed lots, demonstrating that the lettuce is affected by application of this essential oil.

In a study evaluating the allelopathic effect of 112 essential oils, there was a significant reduction in the percentage of germination and root length of lettuce for most treatments with essential oil (Mirmostafaee et al., 2020). These results agree with those observed in the present study, in which the dose of $0.25 \%$ already caused inhibition of the germination of the lettuce seeds and, consequently, decreased both the root length and the shoot length. This can be explained by the possibility of the essential oil having major
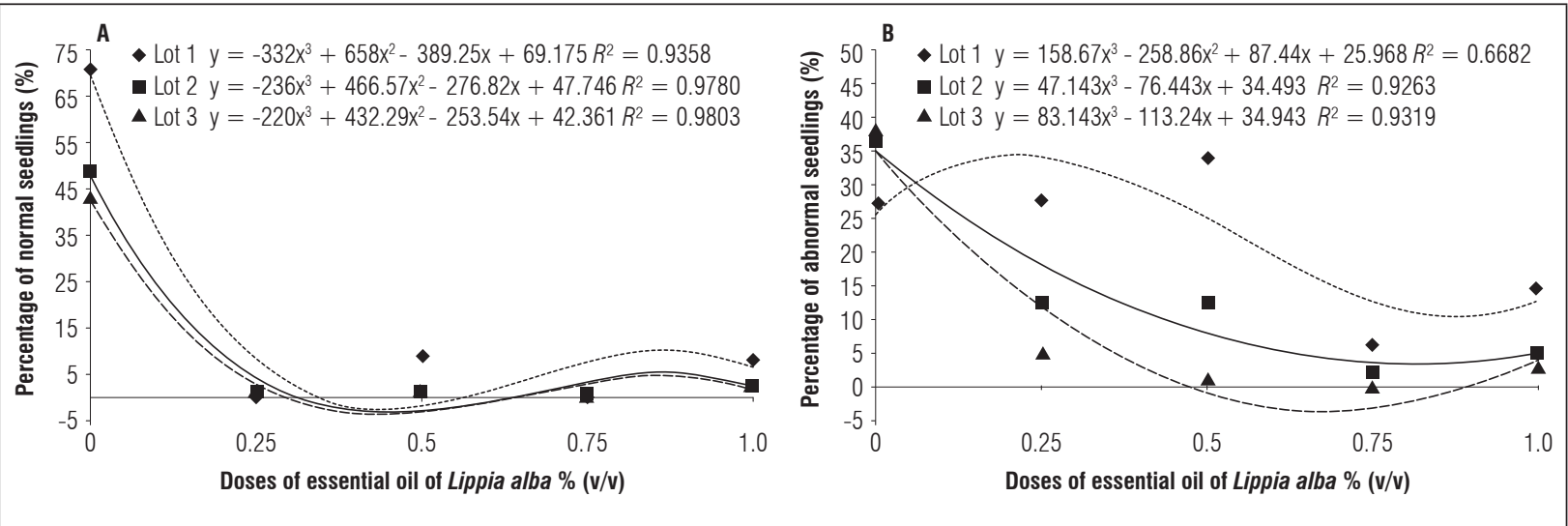

Figure 2. Percentage of normal (A) and abnormal seedlings (B) of commercial lettuce seed lots submitted to different doses of $L$. alba essential oil. 
allochemical components with a greater inhibiting action, thus providing results even with the addition of small concentrations of the oil. The increase in the concentrations of essential oil tends to provide a reduction in germination and GSI precisely because of the increase in the concentration of the components responsible for causing an allelopathic effect. Rosado et al. (2009) observed phytotoxicity from basil essential oil (Ocimum basilicum) in the solution, noting that, with the increase in essential oil concentrations, there was a reduction in the GSI and the percentage of germination lettuce seeds.

For radicle length (Fig. 4A) and shoot length (Fig. 4B), it was observed that the lettuce seeds submitted to treatments with essential oil showed lower values. Similar results were found by Rosado et al. (2009), who found a shorter length of lettuce roots with an increase in the doses of basil essential oil (Ocimum basilicum), obtaining null values for a concentration of $1 \%$. Root deformity is a good parameter for recording seedling abnormality, as this organ is more sensitive to allelopathic action than the shoot (Pires and Oliveira, 2001), in addition to being the organ

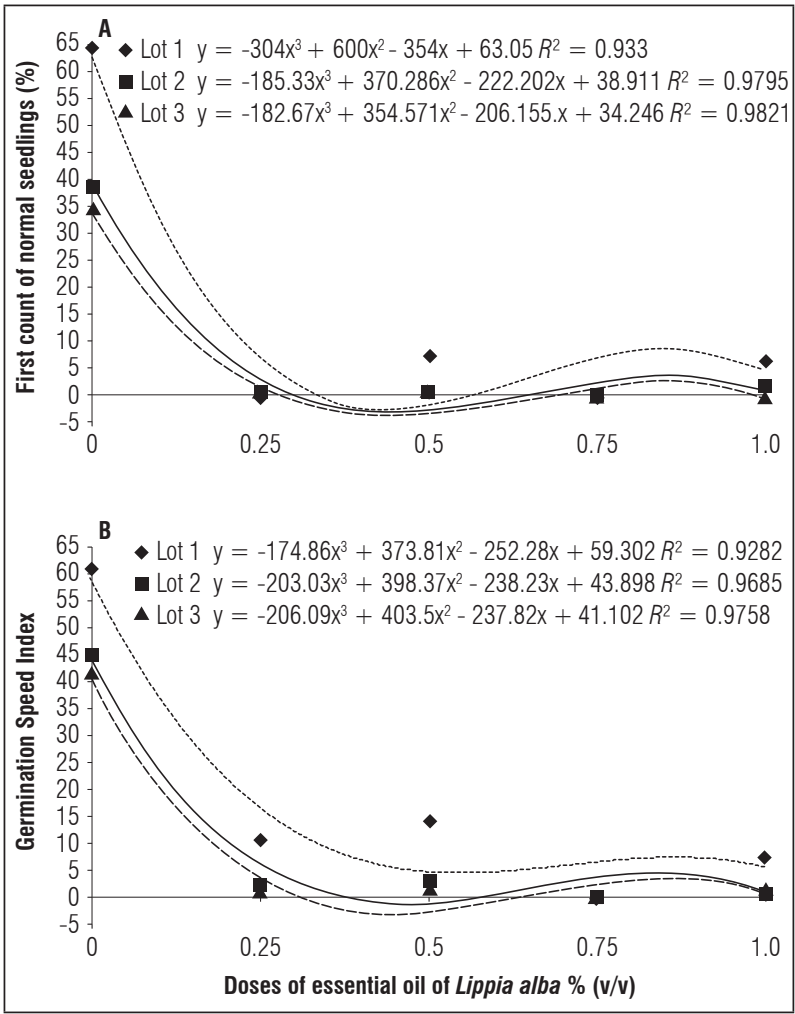

Figure 3. First count of normal seedlings $(A)$ and germination speed index (B) of commercial lettuce seed lots submitted to different doses of $L$. alba essential oil. that remains in direct contact with the essential oil or allelochemical compound.

It was found that the dry mass of the seedling (Fig. 4C) followed the same pattern of reduction as the vigor variables mentioned above; that is, when the essential oil of $L$. alba was added, there was a reduction in the germinative potential of the seeds and the percentage of normal seedlings. Similar results were obtained by Miranda et al. (2015b), who observed that the root and shoot length and the dry mass of the

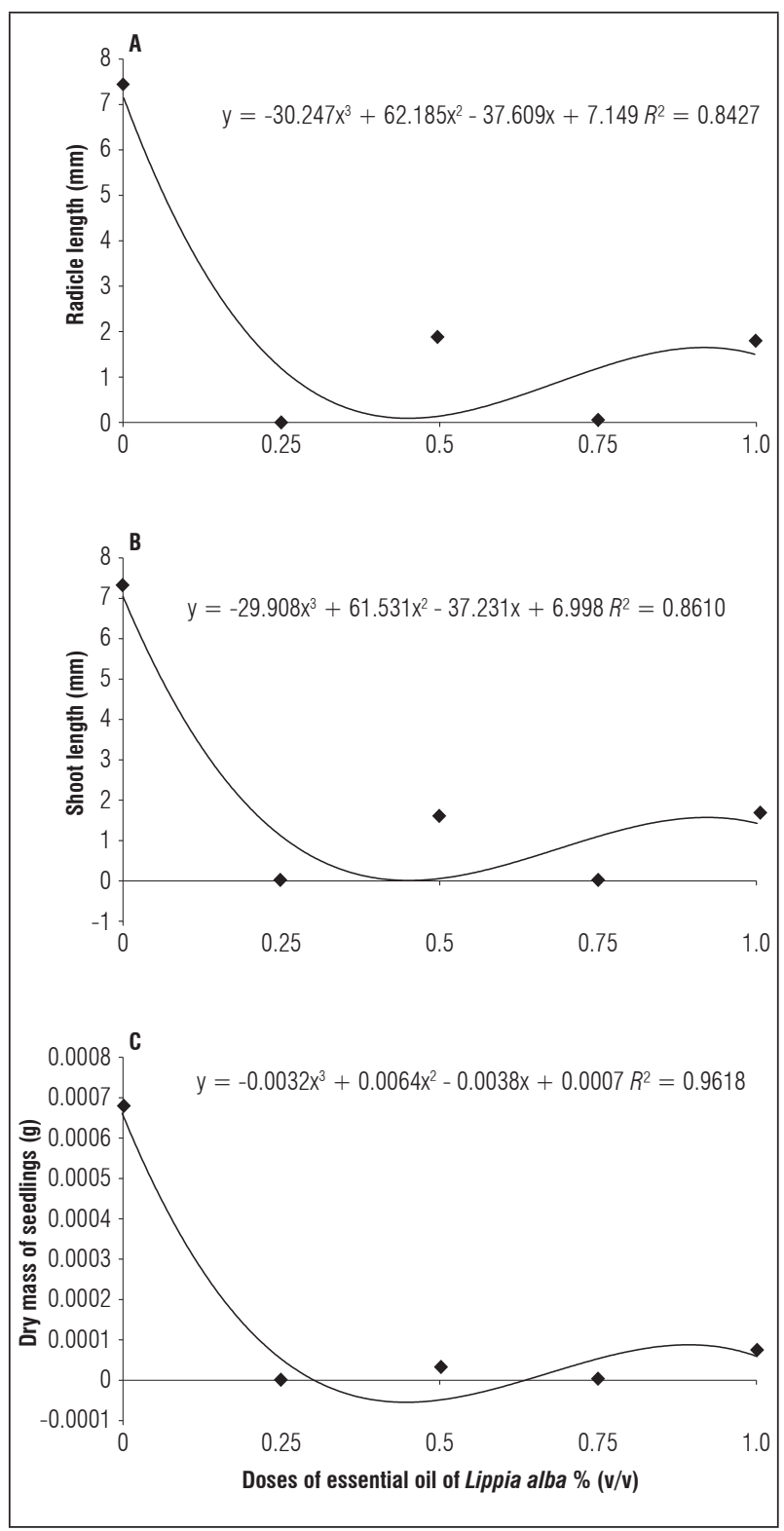

Figure 4. Radicle length (A), shoot length (B) and dry mass of lettuce seedlings (C) in different doses of $L$. alba essential oil. 
seedlings were reduced by an increase in the concentrations of locust essential oil (Ocimum gratissimum). In the present study, the use of essential oil also significantly reduced the root length and the shoot length, with negative consequences in the increase of dry mass of seedlings since it negatively influenced their growth, providing inferior biomass results. That is, it was observed that the L. alba essential oil negatively influenced the variables of first count of normal seedlings, percentage of normal and abnormal seedlings, GSI, radicle length, shoot length and dry mass of seedling, variables that demonstrate the vigor of lettuce seeds.

The averages of the percentage of germinated seeds (Fig. 5A) and the radicle length (Fig. 5B) were significantly higher for lot 1 than the other lots. The reverse was observed for the variable percentage of non-germinated seeds, in which lot 1 had lower values than lots 2 and 3 (Fig. 5A). For the radicle length variable, lot 1 was significantly higher than the other lots (Fig. $5 \mathrm{~B})$. This shows that there is variation in commercial seed lots, and the potential for germination and seed vigor of the same species may vary depending on the different commercial lots (Souza Grzyboyski et al., 2015).

\section{Experiment II: Influence of seed treatment with L. alba essential oil during emergence and growth of lettuce in a protected environment.}

The analysis of variance showed a significant interaction between the lettuce lots and the doses of $L$. alba

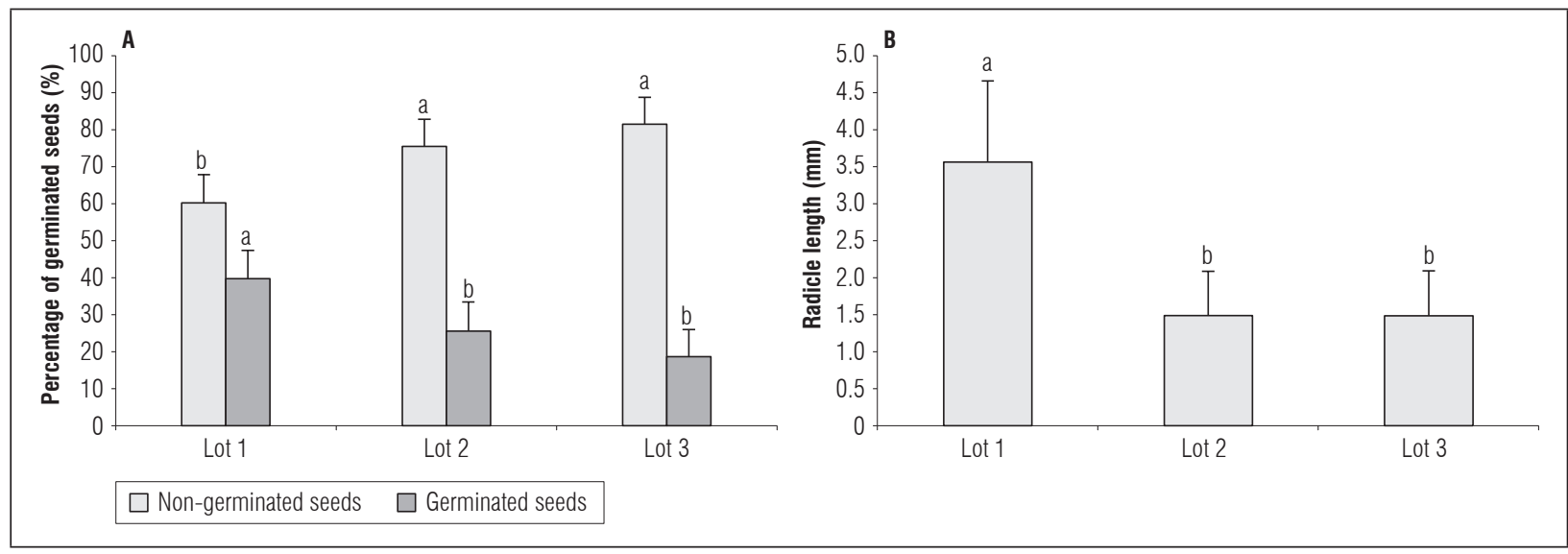

Figure 5. Percentage of germinated and non-germinated seeds $(A)$ and radicle length $(B)$ in the different batches of lettuce seeds. Means with different letters indicate significant statistical difference according to the Tukey test $(P \leq 0.05$; $n=4)$. The vertical bars indicate \pm standard error.

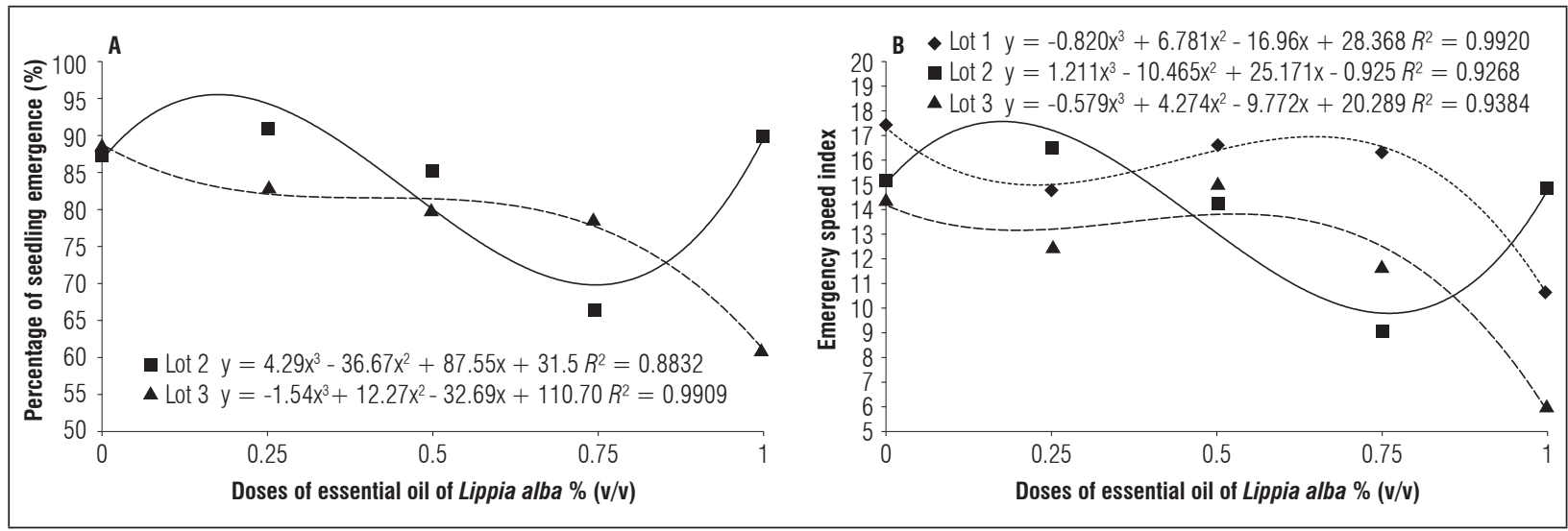

Figure 6. Percentage of seedling emergence (A) and emergence speed index (B) of commercial lettuce seed lots submitted to different doses of $L$. alba essential oil. 
essential oil $(P \leq 0.05)$ for all analyzed variables. For seedling emergence, lots 2 and 3 showed a trend line with cubic performance, with a reduction in emergence with increasing doses of $L$. alba essential oil (Fig. 6A). For variable ESI, lots 1 and 3 showed the same cubic performance, and there was a reduction in this variable when treatments with essential oil were added. Lot 2 had a sharp drop in ESI up to the dose of $0.75 \%$, and, for the dose of $1 \%$, there was an increase, reaching values close to the treatment without essential oil (Fig. 6B).

Maia et al. (2011) observed an allelopathic effect from mint (Mentha $x$ vilosa) on the emergence of lettuce seedlings in two types of soil, without and with previous mint cultivation, in which there was a difference for seedling emergence. In the present study, the results indicated the allelopathic potential of L. alba in seedling emergence and in lettuce seed ESI.

For the root length variable (Fig. 7A), a quadratic trend was observed for lot 2 , with a small increase in root length for doses 0.25 and $0.5 \%$, and, after these doses, it was possible to observe a root length reduction. For lot 3, there was a cubic trend line (Fig. 7A), with a reduction in the root length for all tested essential oil doses, and, after the $0.5 \%$ dose, some stabilization was observed.

For shoot length, it was possible to observe a quadratic response for lots 2 and 3 (Fig. 7B), in which there was a reduction in this variable starting with the $0.25 \%$ dose. For lot 1 , a cubic trend was observed, in which, starting with the $0.25 \%$ dose, there was a reduction in this variable (Fig. 7B). For the variable dry mass of seedling (Fig. 7C), lot 2 showed linear performance, with a positive response for this variable. For lots 1 and 3, a cubic trend was observed, reducing the dry mass of seedlings at a dose of $1 \%$. The fact that no direct differences were observed between the variables root length, shoot length and dry mass of seedlings can be explained by the fact that plants normally intensify enzymatic processes and can resist the effect of inhibitory substances by degrading them through of enzyme activation (Almeida et al., 2011). In addition, the effect of essential oil allelochemicals may present divergent responses for the concentrations used, where low concentrations can stimulate physiological processes and high concentrations tend to inhibit them (Tigre et al., 2012; Saharkhiz et al., 2010 ), changing the responses of vegetables to different concentrations and composition of essential oils.

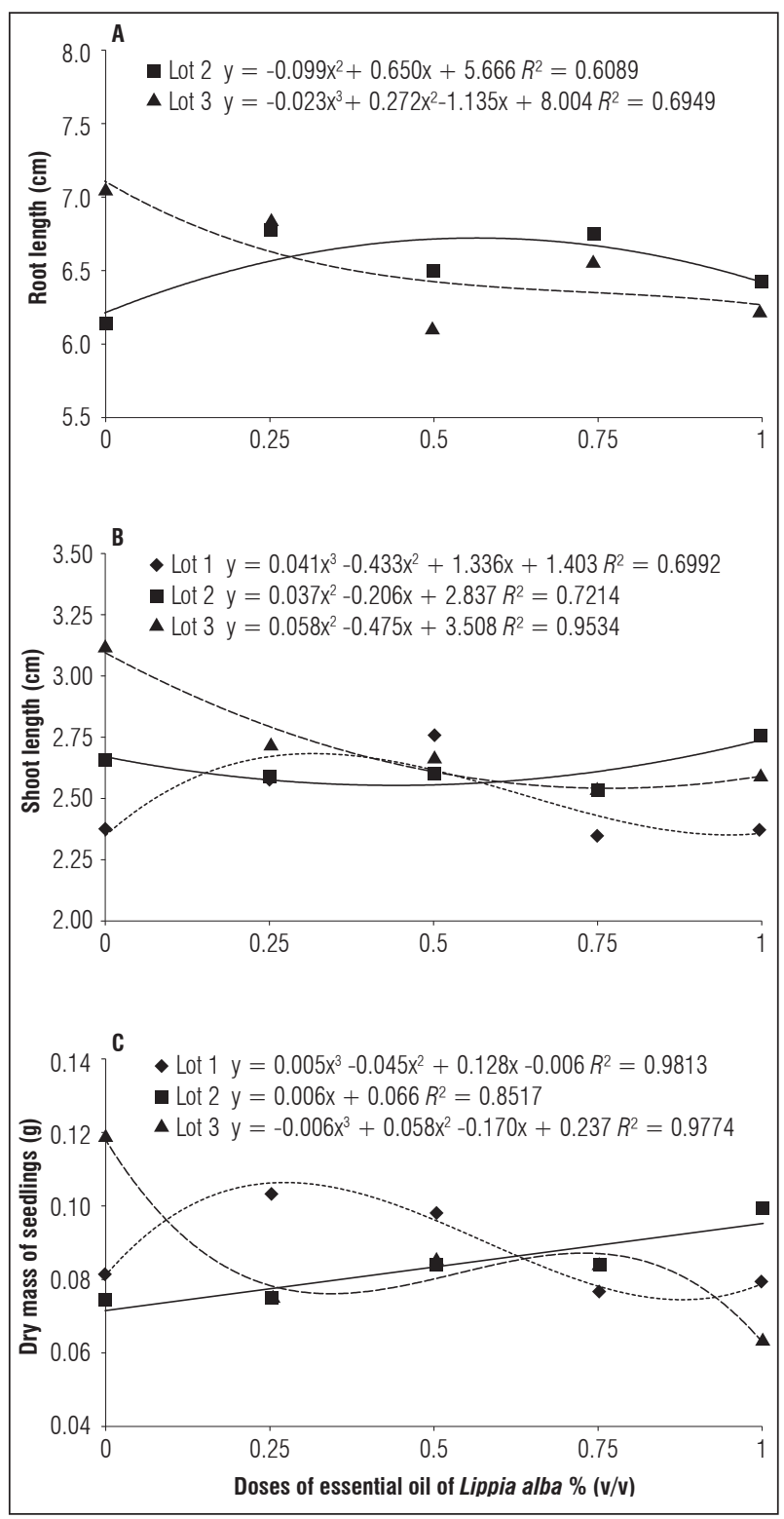

Figure 7. Root length (A), shoot length (B) and dry mass of seedlings (C) of commercial lettuce seed lots submitted to different doses of $L$. alba essential oil.

Therefore, L. alba essential oil has characteristics that inhibit germination and seedling growth, mainly in sensitive species such as lettuce (Lactuca sativa). Because of the sensitivity to the effect of different metabolites, lettuce is commonly used since it is a model species for evaluating the effect of certain allelopathic substances. The responses observed in this study are very promising; however, it is difficult to recommend an ideal concentration or dose that causes greater allelopathic effect since the highest doses were more favorable for reducing germination, emergence and 
seedling growth. Therefore, the allelopathic effect of $L$. alba can be evaluated as a potential herbicide, using it in the control of weed growth in order to avoid unwanted competition with crops of interest. In addition, the composition of the essential oil may vary depending on phytotechnical, physiological and environmental factors, and responses may vary by crop. For this, further research is needed to prove which chemical components present in essential oils have this allelopathic effect, in addition to assessing the potential effect on other species of economic and social importance.

\section{CONCLUSIONS}

Lippia alba essential oil has an allelopathic potential in lettuce culture, negatively interfering with germination and vigor under laboratory conditions and with emergence under protected environment conditions.

\section{ACKNOWLEDGMENTS}

The Coordination of Improvement of Higher Education Personnel (Coordenação de Aperfeiçoamento de Pessoal de Nível Superior - CAPES) for granting scholarship.

Conflict of interest: this manuscript was prepared and reviewed with the participation of all authors, who declare that there exists no conflict of interest that that puts at risk the validity of the presented results.

\section{BIBLIOGRAPHIC REFERENCES}

Almeida, L.F.R., R.S. Polleto, S.Z. Pinho, and M.E.A. Delachiave. 2011. Metodologia para germinação de sementes de Leonurus sibiricus L. Rev. Bras. Plantas Med. 13(2), 190-196. Doi: 10.1590/S1516-05722011000200010

Alvares, C.A., J.L. Stape, P.C. Sentelha, G. Moraes, J. Leonardo, and G. Sparovek. 2013. Köppen's climate classification map for Brazil. Meteorol. Z. 22(6), 711-728. Doi: 10.1127/0941-2948/2013/0507

Arceo-Medina, G.N., J.A. Rosado-Aguilar, R.I. RodríguezVivas, and R. Borges-Argaez. 2016. Synergistic action of fatty acids, sulphides and stilbene against acaricide-resistant Rhipicephalus microplus ticks. Vet. Parasitol. 228, 121-125. Doi: 10.1016/j.vetpar.2016.08.023

Brum, R.B.C.S., H.G. Castro, F.R. Gama, C.H. Gordon, and G.R. Santos. 2014. Phytotoxicity of essential oils in watermelon, bean and rice plants. J. Biotechnol. Biodivers. 5(2), 101-109. Doi: 10.20873/jbb.uft.cemaf.v5n2. brum

Fabri, R.L., M.S. Nogueira, J.D.R. Moreira, M.L.M Bouzada, and E. Scio. 2011. Identification of antioxidant and antimicrobial compounds of Lippia species by bioautography. J. Med. Food. 14(7-8), 840-846. Doi: 10.1089/jmf.2010.0141

Ferreira, D.F. 2011. Sisvar: a computer statistical analysis system. Ciênc. Agrotec. 35(6), 1039-1042. Doi: 10.1590/S1413-70542011000600001

Ferreira, M.C., J.R.P. Souza, and T.J. Faria. 2007. Potenciação alelopática de extratos vegetais na germinação e no crescimento inicial de picão-preto $e$ alface. Ciênc. Agrotec. 31(4), 1054-1060. Doi: 10.1590/ S1413-70542007000400017

Garbim, T.H.S., E.D.B. Romano, S.M.T.P.G. Carneiro, and M.L.V. Souza. 2015. Efeito do óleo essencial de eucalipto sobre a germinação e o crescimento de rabanete e alface. SaBios: Rev. Saúde e Biol. 10(1), 52-58.

Gliessman, S.R. 2009. Agroecologia: bases conceituais para a sustentabilidade na agricultura. Editora da Universidade-UFRGS, Alegre, Brazil.

Gusman, G.S., L.R. Vieira, and S. Vestena. 2012. Alelopatia de espécies vegetais com importância farmacêutica para espécies cultivadas. Rev. Biot. 25(4), 37-48. Doi: 10.5007/2175-7925.2012v25n4p37

Li, J., X. Liu, F. Dong, J. Xu, Y. Li, W. Shan, and I. Zheng. 2011. Potential allelopathic effects of volatile oils from Descurainia sophia (L.) Webb ex Prantl on wheat. Biochem. Syst. Ecol. 39(1), 56-63. Doi: 10.1016/j. bse.2010.12.022

Ma, J., G. Xing, W. Yang, L. Ma, M. Gao, Y. Wang, and Y. Han. 2012. Inhibitory effects of leachate from Eupatorium adenophorum on germination and growth of Amaranthus retroflexus and Chenopodium glaucum. Acta Ecol. Sin. 32(1), 50-56. Doi: 10.1016/j.chnaes.2011.12.004

Maguire, J.D. 1962. Speed of germination - aid in selection and evaluation for seedling emergence and vigor. Crop Sci. 2(2), 176-177. Doi: 10.2135/ cropsci1962.0011183X000200020033x

Maia, J.T.L.S., F.P.G. Bonfim, C.K.R. Barbosa, D.O. Guilherme, I.C.G. Honório, and E.R. Martins. 2011. Influência alelopática de hortelã (Mentha $x$ villosa Huds.) sobre emergência de plântulas de alface (Lactuca sativa L.). Rev. Bras. Pl. Med. 13(3), 253-257. Doi: 10.1590/S1516-05722011000300001

MAPA, Ministério da Agricultura, Pecuária e Abastecimento. 2009. Regras para análise de sementes. Brasilia.

Marco, C.A., H.R. Santos, A.G.S Feitosa, J.V. Feitosa, and J. G.M Costa. 2015. Teor, rendimento e qualidade do óleo essencial de Vanillosmopsis arborea (Gardner) Baker 
(candeeiro) e sua ação alelopática. Rev. Cubana Plant. Med. 20(1), 131-141.

Mamun-Or-Rashid, A.N.M., M.K. Sen, M.A. Jamal, and S. Nasrin. 2013. A comprehensive ethno-pharmacological review on Lippia alba M. Int. J. Biomed. Mat. Res. 1(1), 14-20. Doi: 10.11648/j.ijbmr.20130101.13

Miranda, C.A.S.F., M.G. Cardoso, M.L.M. Carvalho, S.M.F. Machado, M.A. Andrade, and C.M. Oliveira. 2015a. Análise comparativa do potencial alelopático do óleo essencial de Thymus vulgaris e seu constituinte majoritário na germinação e vigor de sementes de alface (Lactuca sativa L.). Rev. E-xacta, 8(2), 45-53. Doi: 10.18674/ exacta.v8i2.1516

Miranda, C.A.S.F., M.G. Cardoso, M.L.M. Carvalho, S.M.F. Machado, M. Souza Gomes, J. Andrade, and M.L. Teixeira. 2015b. Allelopathic activity of medicinal plant essential oils on seed germination and vigor of lettuce achenes. Sem. Cienc. Agrar. 36(3), 1783-1798. Doi: 10.5433/1679-0359.2015v36n3Supl1p1783

Mirmostafaee, S., M. Azizi, and Y. Fujii. 2020. Study of Allelopathic Interaction of essential oils from medicinal and aromatic plants on seed germination and seedling growth of lettuce. Agronomy 10(2), 163. Doi: 10.3390/agronomy10020163

Oliveira, G.T., J.M.S. Ferreira, W.G. Lima, L.F. Alves, J.M. Duarte-Almeida, and L.A.R.S. Lima. 2018. Phytochemical characterization and bioprospection for antibacterial and antioxidant activity of Lippia alba Brown ex Britton \& Wilson (Verbenaceae). Nat. Prod. Res. 32(6), 723-731. Doi: 10.1080/14786419.2017.1335727

Oliveira, G.T., P.A Amado, J.M S. Ferreira, and L.A.R.S. Lima. 2019. Allelopathic effect of the ethanol extract and fractions of the aerial parts of Lippia alba (Verbenaceae). Nat. Prod. Res. 33(16), 2402-2407. Doi: 10.1080/14786419.2018.1443090

Pires, N.M. and V.R. Oliveira. 2001. Alelopatia. pp.145185. In: Oliveira Jr., R.S. and J. Constantin (Coords.). Plantas daninhas e seu manejo. Agropecuária, Guaiba, Brazil.

Rosado, L.D.S., H.C.A. Rodrigues, J.E.B.P. Pinto, T.N. Custodio, L.B.B. Pinto, and S.K.V. Bertolucci. 2009. Alelopatia do extrato aquoso e do óleo essencial de folhas do manjericão "Maria Bonita" na germinação de alface, tomate e melissa. Rev. Bras. Pl. Med. 11(4), 422-428. Doi: 10.1590/S1516-05722009000400010

Saharkhiz, M.J., S. Esmaeili, and M. Merikhi. 2010. Essential oil analysis and phytotoxic activity of two ecotypes of Zataria multiflora Boiss. growing in Iran. Nat. Prod. Res. 24(17), 1598-1609. Doi: 10.1080/14786411003754280

Santos, C., A. Franco-Rodrigues, G. Araujo, S. Scalon, and M. Vieira. 2019. Impacto del fósforo y luminosidad en la propagación, reacciones fotoquímicas y calidad de plántulas de Lippia alba (Mill.) N.E.Br. Rev. Colomb. Cienc. Hortic. 13(2). Doi: 10.17584/ rcch.2019v13i2.9023

Silva, C.B., E. Simionatto, S.C. Hess, M.T.L.P. Peres, E.L. Simionatto, A. Wisniewski Júnior, N.R. Poppi, O. Faccenda, A.C.S. Cândido, and S.P.Q. Scalon. 2009. Composição química e atividade alelopática do óleo volátil de Hydrocotyle bonariensis Lam (Araliaceae). Quím. Nova. 32(9), 2373-2376. Doi: 10.1590/ S0100-40422009000900026

Souza Grzybowski, C.R., R.D. Vieira, and M. Panobianco. 2015. Testes de estresse na avaliação do vigor de sementes de milho. Rev. Ciênc. Agron. 46(3), 590-596. Doi: 10.5935/1806-6690.20150042

Taiz, L., E. Zeiger, I.A. Moller, and A. Murphy. 2017. Fisiologia e desenvolvimento vegetal. $6^{\text {th }}$ ed. Artmed, Porto Alegre, Brazil.

Tavares, E.S., L.S. Julião, D. Lopes, H.R. Bizzo, C.L.S. Lage, and S.G. Leitão. 2005. Análise do óleo essencial de folhas de três quimiotipos de Lippia alba (Mill.) N.E. Br. (Verbenaceae) cultivados em condições semelhantes. Rev. Bras. Farmacogn. 15(1), 1-5. Doi: 10.1590/ S0102-695X2005000100002

Tavares, I.B., V.G. Momenté, and I.R. Nascimento. 2011. Lippia alba: estudos químicos, etnofarmacológicos e agronômicos. Pesq. Aplic. Agrotec. 4(1), 204-220. Doi: 10.5777/PAeT.V4.N1.12

Tigre, R.C., N.H. Silva, M.G. Santos, N.K. Honda, E.P.S. Falcao, and E.C. Pereira. 2012. Allelopathic and bioherbicidal potential of Cladonia verticillaris on the germination and growth of Lactuca sativa. Ecotoxicol. Environ. Saf. 84(1), 125-132. Doi: 10.1016/j. ecoenv.2012.06.026 